\title{
The importance of women in the preservation of the companies dedicated to the production and sale of the Jipi-Japa hat in the Maya area of Calkiní
}

\section{Importancia de la mujer en la preservación de las empresas dedicadas a la producción y venta del sombrero de Jipi-Japa en la zona Maya de Calkiní}

\author{
LÓPEZ-PONCE, María Eugenia†*1', SANTOS-VALENCIA, Raúl Alberto², BACAB-SÁNCHEZ, José \\ Rubén $^{1}$ and ORTEGA-RODRÍGUEZ, Ana Luisa ${ }^{3}$
}

\author{
${ }^{1}$ Instituto Tecnológico Superior de Calkiní en el Estado de Campeche, (Tecnológico Nacional de México) \\ ${ }^{2}$ Instituto Tecnológico de Mérida \\ ${ }^{3}$ Instituto Tecnológico de Campeche
}

ID 1st Author: López-Ponce, María Eugenia / ORC ID: 0000-0001-7030-1843, CVU CONACYT ID: 503775

ID $1^{\text {st }}$ Co-author: Santos-Valencia, Raúl Alberto / ORC ID: 0000-0002-9824-8789, CVU CONACYT ID: 375284

ID $2^{\text {nd }}$ Co-author: Bacab-Sánchez, José Rubén / ORC ID: 0000-0002-8861-0852, CVU CONACYT ID: 96835

ID $3^{\text {rd }}$ Co-author: Ortega-Rodríguez, Ana Luisa / ORC ID: 0000-0002-0134-2008, CVU CONACYT ID: 228237

\begin{abstract}
In the Yucatán península, the handicraft businesses tend to disappear when the master craftsman dies, losing these family type companies. According with researches applied by Santos y Barroso (2016), point out that the $66 \%$ of the companies are run by handicraft woman, who preserve their customs, traditions and handicraft heritage. This document aims to appreciate the importance of the women in the preservation of the companies dedicated to the production and commercialization of the JipiJapa hat in the mayan area from Calkiní, in order to know the strengths and weaknesses of these companies for the export to European Markets. The research proposal was mixed and it was carried out in the four mayan localities: Tankuche, Bécal, Santa Cruz ex-Hacienda y San Nicólas from the municipality of Calkiní, in the state of Campeche, in two phases: Phase 1.Internal analysis of the handicraft's companies. Phase 2.External analysis of the handicraft's companies through key informants. The results point out that even when the woman has an important leading role in this activity, there is a significant decrease in their number; which indicates, that the new generations do not see the handicraft production attractive perhaps because of the work it implies and the low remuneration, putting at risk the generation of jobs derived from this activity; For this reason, it is urgent to implement strategies in the production and commercialization of the hat that help to strengthen this activity and prevent its extinction.
\end{abstract}

Preservation, Production, Hat, Handicrafts

\begin{abstract}
Resumen
En la península de Yucatán, las empresas artesanales tienden a desaparecer cuando el maestro artesano muere, perdiéndose dichas empresas de tipo familiar. Según estudios realizados por Santos y Barroso (2016), señalan que el 66\% de estas empresas están dirigidas por mujeres artesanas, quienes preservan sus costumbres, tradiciones, y acervo artesanal. En este documento se pretende apreciar la importancia de la mujer en la preservación de las empresas dedicadas a la producción y comercialización del sombrero de Jipi-japa en la zona maya de Calkiní, a fin de conocer las fortalezas y debilidades de estas empresas para la exportación a mercados europeos. El estudio propuesto fue mixto y se realizó en las cuatro localidades mayas: Tankuché, Bécal, Santa Cruz ex-hacienda y San Nicolás del Municipio de Calkiní, en el Estado de Campeche, en dos fases: Fase 1: Análisis interno de las empresas artesanales. Fase 2: Análisis externo de las empresas artesanales por medio de informantes claves. Los resultados indican que, aun cuando la mujer tiene un papel preponderante en esta actividad, se observa una importante disminución en su número; lo cual indica, que las nuevas generaciones no ven atractiva la producción artesanal quizá por el trabajo que implica y la baja remuneración poniendo en riesgo la generación de empleos derivado de esta actividad; por tal motivo, es urgente implementar estrategias en la producción y comercialización del sombrero que coadyuven a fortalecer esta actividad y evitar su extinción.
\end{abstract}

Preservación, Producción, Sombrero, Artesanías

Citation: LÓPEZ-PONCE, María Eugenia, SANTOS-VALENCIA, Raúl Alberto, BACAB-SÁNCHEZ, José Rubén and ORTEGA-RODRÍGUEZ, Ana Luisa. The importance of women in the preservation of the companies dedicated to the production and sale of the Jipi-Japa hat in the Maya area of Calkiní. Rinoe Journal-Industrial Organization. 2021. 5-8: 10-20

\footnotetext{
*Correspondence to Author (melopez@itescam.edu.mx)
}

$\dagger$ Researcher contributing first author. 


\section{Introduction.}

In Campeche, the handicrafts family type businesses have survived over the centuries. A large part of these companies are run by women who with their talent, perseverance and dedication have managed to create and position hadicrafts products of recognized prestige at a national and international level; However, it has been observed that, during the last decade, these types of companies disappear when the master craftsman dies.

The companies dedicated to the production and commercialization of the Jipijapa palm hat (Carludovica palmata) in the Mayan area of the north of the State of Campeche, offer employment to the inhabitants of four towns in the municipality of Calkiní, this situation determines the need to carry out this basic research that allows finding strategies to guide the planning of actions that could lead to the preservation or rescue of this valuable handicraft activity and leave to future generations, the extensive, traditional and ancient artisan heritage, legacy of the Mayan culture.

Similarly, it is necessary to improve the quality of life of the inhabitants of these communities and / or regions through the strengthening of micro and small handicraft compannies, which will also increase sources of employment, reducing migration to urban centers, reduction of the poverty that exists among the people of the Mayan areas of the State of Campeche, but above all of the so-called Camino Real integrated by the Municipalities of Tenabo, Hecelchakán and Calkiní.

And as an added value of this research, it seeks to dignify the relevant role that handicraft women have in the contribution of family spending, since it is observed that they tend to adopt different and different roles in the social structure of Mayan communities, since in addition to being artisans, they must adopt the roles of: wife, mother and businesswoman; For this reason, one must be aware that this traditional handicraft mode of production can be forgotten and be lost, since in recent years the boom in crafts and families dedicated to this work has declined;
All this problem is caused by the famous era of technology since now people prefer to buy imitations at lower prices and thus discredit the crafts, that is why many of the artisans have sought in other activities the way to earn a living; All this is also coupled with the government's lack of vision and empathy, without public policies that allow the necessary support, the Mayan cultural heritage could disappear.

There is a diversity of problems that afflict the artisanal activity, in relation to the elaboration of hats there is a great diversity of aspects that have been flourishing and contributing so that this valuable activity disappears, the following can be mentioned: (1) The production of the Jipi-japa palm, has decreased because the lands do not have adequate conditions for palm cultivation, which makes the process slower and with less production. These plants require a lot of water; This being a determining factor since in this Mayan area the soils are dry and stony. (2) The irrigation techniques that are currently used in some areas are the system through irrigation strips, which helps the growth of the plant. (3) The time to harvest the plant is one and a half to two years to cut the buds that the handicraft uses to make the hat. (4) According to the new regulations, according to what is established by the Ministry of Finance and Public Credit (MFPC), all operation that leads to a purchasesale must be declared and invoiced, this being totally difficult for the artisan who cultivates it. in a homemade way, since it is not $100 \%$ dedicated to this activity.

\section{Context}

The United Nations Educational, Scientific and Cultural Organization (UNESCO, 2012) recognized crafts as a cultural expression that is currently threatened by globalization, which creates strong obstacles to the survival of traditional forms of handicrafts, such as: mass production, environmental and climatic pressures, and land deforestation. The Handicraft companies are found throughout the country and constitute an important factor in the national economic system, both for their contribution to employment and for their contribution to the Gross Domestic Product (GDP). 
The Center for Social Studies and Public Opinion (CESOP, 2011), points out that in Mexico during the third quarter, more than one million eight hundred thousand people over 15 years of age were employed in some craft or related activity, of which 507,368 worked as part of the full-time employed population and the rest as underemployed population, (Sales, 2013).

However, although there is much information on micro and small family-type businesses, little research has been carried out on artisan-type businesses, since, due to their own conditions to produce handicraft-type goods or services, they do not have large machinery, tools or equipment that allows them to carry out their activities quickly, uniformly or with unique quality, as demanded by international or national markets today.

However, this activity allows artisans to contribute to the spending of their families and the creation of jobs for family members. For some years now, since there has been the perception that master craftsmen are generally older adults and owners of companies, they do not transmit all their knowledge and technique to their children and grandchildren, but the most important thing is the role that the artisan woman plays in the preservation of the Jipi-japa hat by contributing in the same way to family spending, where many artisans do not see this activity as a business that allows them to have an income to live decently and therefore, do not wish to continue with the tradition artisan and look for other sources of employment where they can enjoy a secure salary. In the Yucatan peninsula, artisan companies tend to disappear when the master craftsman dies, thereby losing a familytype business, sources of employment, tradition and above all a considerable and millenary source of knowledge.

In the State of Campeche, there are 4 regions:

1. The mountain region that includes the Municipalities of Calkiní, Hecelchakán, Hopelchén and Tenabo; This region is characterized by being an indigenous Mayan region, cataloged by the Consejo Nacional de Evaluación de la Politica de Desarrollo Social (CONEVAL, 2014) as a region of extreme poverty. For this reason, there are very few companies, the main activities being agriculture and handicraft production.
2. The region of La Selva: it is made up of the Municipality of Calakmul. As in the mountain region, this region is characterized by being a region of extreme poverty. The main activities are: agriculture, livestock, forestry and tourism.

3. The river region: this region is made up of the municipalities of Escárcega, Candelaria and Palizada. The main economic activities are: fishing, agriculture, livestock and tourist services. This region is classified as extreme poverty.

4. The region of the Coast: made up of the Municipalities of Campeche, Champotón and Carmen This region is the most economically developed, where $95 \%$ of the State companies are located and its main activities are fishing, agriculture, livestock, commerce, tourism and government. However, except for the State Capital and the town of Carmen in the Municipality of the same name, the entire region is classified as a region of extreme poverty.

As can be seen, most companies are in two locations: San Francisco de Campeche (State Capital) and Carmen. Therefore, promoting the generation or strengthening of companies within the State is a fundamental task to prevent the migration of people from rural areas to these localities; avoiding, in this way, the social problems that afflict cities. In relation to the Economic strength of the State of Campeche, according to the National Institute of Statistics and Geography (INEGI, 2013), this amounted and according to GDP to more than 710 billion pesos for the State of Campeche, which placed us as the sixth largest entity in the country according to axis 2 Economic Strength, (State Development Plan, 2015-2021). The percentage share of GDP indicates that the primary sector represents 0.59 percent of the state economy; the secondary sector, which constitutes 87.1 percent, and the services sector, which accounts for 12.3 percent. objective:

The present investigation has as a general 
Qualify the importance of women in the preservation of the companies dedicated to the production and commercialization of the Jipijapa hat in the Mayan Zone of Calkiní. Regarding the specific objectives, we consider:

1. Analyze the level of participation of women in the preservation of artisan companies dedicated to the production of the Jipi-japa hat in the Mayan Zone of Calkiní.

2. Identify the strengths and weaknesses in family-type craft businesses, run by women and dedicated to making Jipijapa hats.

3. Determine the risk factors in the production and marketing of hats in artisan companies run by women.

Carrying out this study and the impact it is intended to achieve is based fundamentally on axis 2, according to (State Development Plan, 2015-2021) and on National Strategy II. Social Policy: Promote economic reactivation, the internal market and employment according to (National Development Plan, 2019-2024), in which the federal government will promote the modalities of fair trade and social and solidarity economy (page 51), bearing in mind that these types of activities, such as crafts, are an essential pillar to promote and grow the economy of the state itself.

According to the previous section, it is also sought to promote the wealth of the State; as it is in this case the Mayan crafts based on axis 3 according to (State Development Plan, 20152021) where it establishes that the work and talent from the Campeche people is manifested through their crafts, currently, there are more Out of 10,000 artisans in the entity, the largest number is in the municipalities of Calkiní 43\%, Hopelchén 15\%, Campeche 10\%, Hecelchakán 9\% and Carmen 4\%. This project directly benefits the artisans, their children and other people who indirectly help with the production of hats, with 8 basic steps from beginning to end for their elaboration, Chuc (1999): 1.- Cut the Bud; 2.- The scratching or incision to form the "strands"; 3.- Bleached; 4.- The selection of skeins or strands; 5.- The mooring of the bottom of the glass; 6.- Interlacing of the bottom of the glass; 7.- Bending of the cup; 8.- Pressing; (see figure 1).

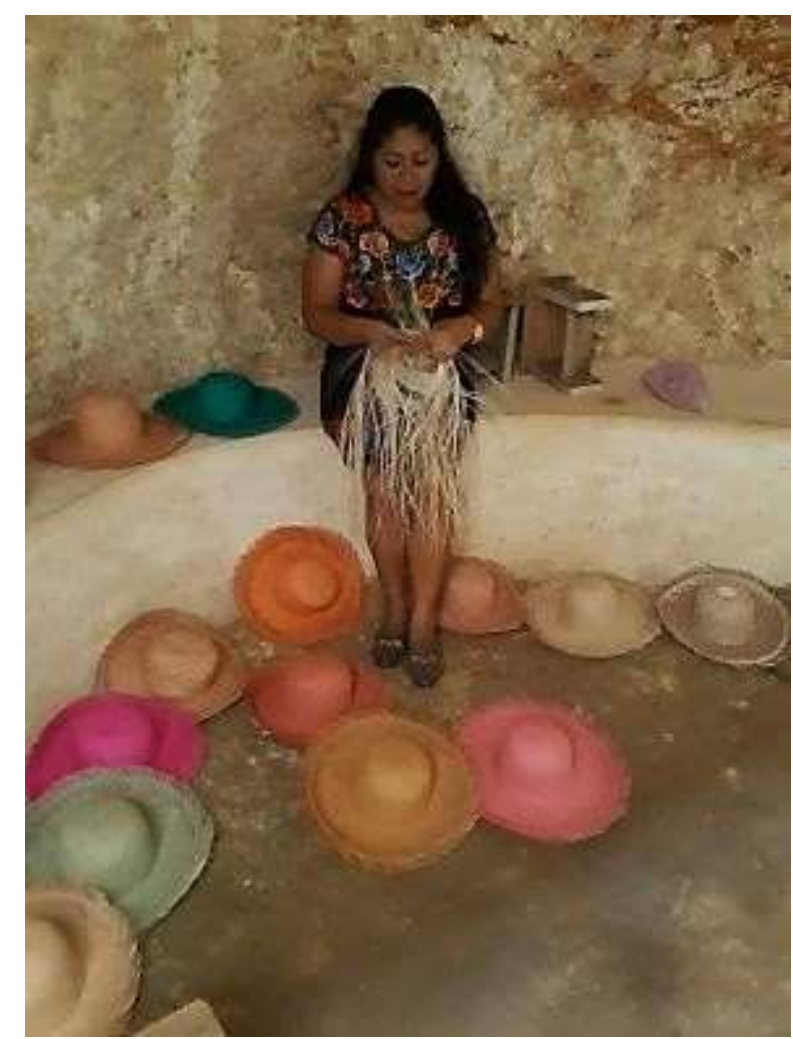

Figure 1 Elaboration of the hat Jipi japa

Source: Own elaboration, 2020.

It is important to note that jipijapa weaving is done in caves; mainly due to the temperature and humidity conditions found in them, which makes it possible for the palm fibers not to dry out and become brittle when weaving. For this reason, caves are an essential means of making the hat. In the same way, there is a strong relationship in terms of time and the amount of material used in the elaboration of the hat, since the artisans call the thickness of the fiber batches, so we have to use a batch for the production of hats with fabric. or thick woven fabric, two items for medium fabrics, three items for fine fabrics and four items for extra-fine fabrics; being these items, a synonym of the quality of the hat because the greater the number of items, the higher the quality of the hat; but also, they have a longer time in the elaboration and, consequently, a greater amount of raw material used.

\section{Methodology}

The research work was divided into two phases:

Phase 1. Internal analysis of the handicraft companies in which it is intended to determine the strengths and weaknesses of the critical factors that would favor the creation or preservation of these companies in four localities of the Municipality of Calkiní, Campeche, dedicated to the elaboration of Jipi- hats. japa. 
Phase 2. External analysis of opportunities and threats of handicraft companies to qualify the importance of women in the preservation of the Jipi-japa hat, through the judgment of experts.

\section{Study type and design}

To determine the strengths and weaknesses of the artisan companies dedicated to the elaboration of hats in the towns of Tankuché, Bécal, Santa Cruz Ex-hacienda and San Nicolás of the Municipality of Calkiní, Campeche and the factors to consider to qualify the importance of women In the preservation of the companies dedicated to the production and commercialization of Jipi-japa hats, the type of study begins as exploratory, evolving to descriptive, with a mixed approach and nonexperimental, transectional design, since, although it is carried out in artisan companies of the family of Mayan areas.

It is carried out in a single time and space (Hernández, Fernández \& Baptista, 2014), with the aim of describing variables and analyzing their incidence or interrelation in a single moment. The method used is field work, using the survey as a technique and the questionnaire and the interview were used as instruments.

For the artisans and their children, the questionnaire was used as an instrument to collect information (quantitative approach) and for key informants from the artisan sector, a structured interview was had as an instrument (qualitative approach). An analysis was carried out on the results of these two instruments.

\section{Participants in the Study}

From a total of 10,357 artisans registered in the State Institute for the Promotion of Artisan Activities of Campeche (INEFAAC, 2013); A census was carried out in the four study locations: Tankuché, Santa Cruz Exhacienda, San Nicolás and Bécal of the Municipality of Calkiní, to a total of 130 artisans dedicated to making the Jipi-japa hat.

For the interview, it was administered to three experts in the handicraft sector as key informants, who were selected for convenience by virtue of their knowledge, involvement, and experience in the subject matter.
The characteristics of the study participants are described below:

a) For the handicraft teachers, the following were categorized:

1. Women who carry out some craft activity.

2. With residence in one of the towns of Tankuché, Santa Cruz Exhacienda, San Nicolás and Bécal in the municipality of Calkiní.

3. With knowledge and experience in the elaboration of handicrafts, at least 5 years.

b) For experts in craft activities:

1. Those who are or have worked, up to three years ago, in an organization or agency where they are linked to craft activities.

2. That they have had contact with the artisan communities.

3. That they have knowledge of the current problems of the artisan sector.

The experts in the artisanal sector were selected on a discretionary basis, taking into consideration their knowledge and experience in the subject matter.

\section{Instrument}

In the present work, the questionnaire was used as an instrument for collecting information. In the elaboration of the questionnaire of the handicraft teachers, quite extensive information was obtained in three sections: the first section is about the data of the respondents and school data, that is, it was verified that the participants have the characteristics of the population under study. Questions such as age, gender, place of birth, municipality, etc. were included. In the second section, 28 items were included, of which 3 were open questions and the rest were multiple-choice, where information was obtained regarding the production and marketing of Jipi-japa hats.

\section{Process}

The contact with the companies was made in a personalized way in each of the respective regions studied. In the administering of the questionnaires, the following was considered: 
In addition to the researcher and a work team, there were two support teams to carry out the surveys; These teams were students of the Educational Program of the Bachelor of Administration, of the Calkiní Higher Technological Institute in the State of Campeche, who were previously trained in the administration of these instruments, in order to homogenize criteria, clear up doubts and, in general terms, survey the selected people without any setback.

The interviews were conducted personally with each of the experts selected at their discretion. Once the instruments were administered to the experts, the data collected was constructed. At this point the information was collected, ordered, and classified. The variables studied and the results of the factors or areas most influencing the problem of artisan companies were analyzed, as well as the most recommended solutions.

With the data obtained from the quantitative analysis of these instruments, the values obtained in this analysis and the most relevant points of the variables studied were interpreted. From here we proceeded to the analysis of the study variables that allowed us to qualify the importance of women in the preservation of the artisan enterprises of Jipijapa.

\section{Information analysis plan}

Descriptive statistics were used for the quantitative analysis and the results were presented through graphs. Once the information was collected, the information was analyzed using Excel utilities, the statistical program SPSS (Statistical Package for the Social Sciences). For the quantitative data, the analysis of the expert testimony phrases was performed. They were grouped by frequency of mention and organized into defined categories (ÁlvarezGayou, 2003).

\section{Results}

\section{1) Quantitatives}

In the initial results, it is observed that the gender of the craftsman dedicated to the elaboration of hats of the four studied localities is $45.6 \%$ for the masculine gender and $54.4 \%$ for the feminine gender (see figure 2).

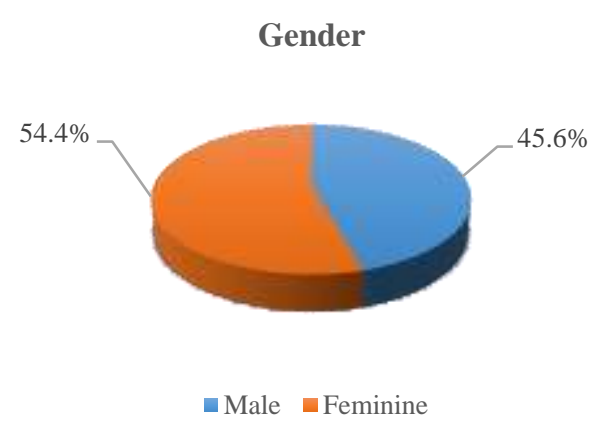

Figure 2. Gender of the craftsman dedicated to the elaboration of the hats

Source: Own Elaboration, 2020

Considering the objective of the investigation, the expected products and results are expected to be the following:

1. An instrument that will allow to identify the opportunities, threats, strengths, and weaknesses of the artisan companies dedicated to the production and commercialization of jipi japa hats of the four Mayan towns of Tankuché, Bécal, Santa Cruz ex-hacienda and San Nicolás del Municipio from Calkiní, Campeche.

2. An instrument that will allow deducing, from the perspectives of the participants, the problem of the craft activity and the proposed solution.

3. Information that could explain the importance of women in this craft activity.

In figure 3, it was observed that $36.9 \%$ of the Craftswomen are between 40 and 49 years old; However, it is observed that the new generations are significantly reduced, since only $3.8 \%$ are between 20 and 29 years old and $16 \%$ of them are between 30 and 39 years old.

$$
\text { Age of the Craftswomen }
$$

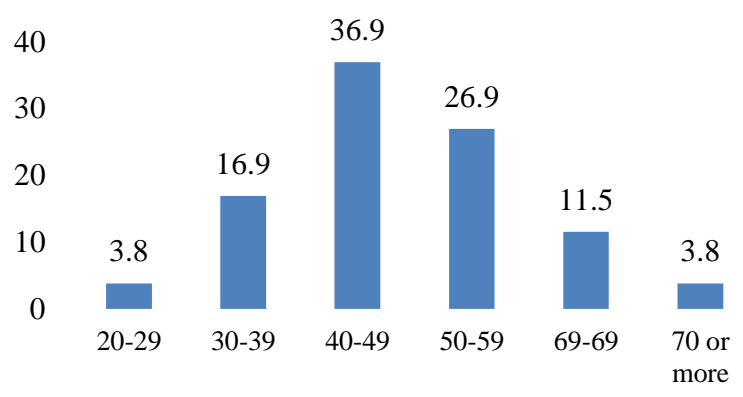

Figure 3. Age of the craftswomen dedicated to the elaboration of hats

Source: Own Elaboration, 2020 
Regarding education, $42.3 \%$ of them have an elementary education, followed by $32.3 \%$ of them who have junior high; however, $19.2 \%$ of these cannot read or write (see figure 4).

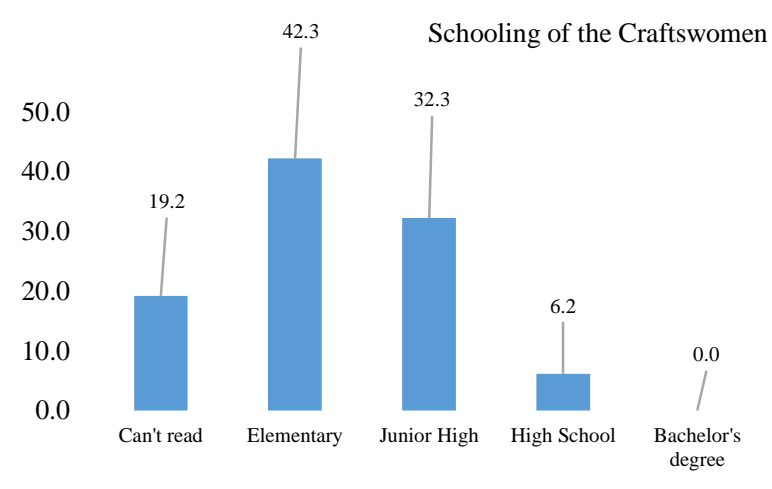

Figure 4 Schooling of the Craftswomen dedicated to the elaboration of the hats

Source: Own Elaboration, 2020

In figure 5 , it is observed that $63 \%$ of the respondents are artisan teachers since they have been working hat weaving for more than 10 years and $31.8 \%$ of them are apprentices.

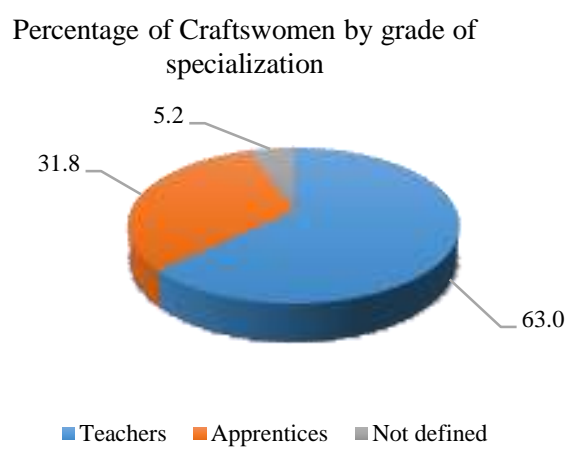

Figure 5. Percentage of craftswomen by grade of specialization dedicated to the elaboration of hats.

Source: Own Elaboration, 2020

\section{Production}

According to the study, $53.1 \%$ of the surveyed craftswomen mentioned that they have their own caves where they make the weaving of the hat (see figure 6).

\section{Craftswomen who have their own caves}

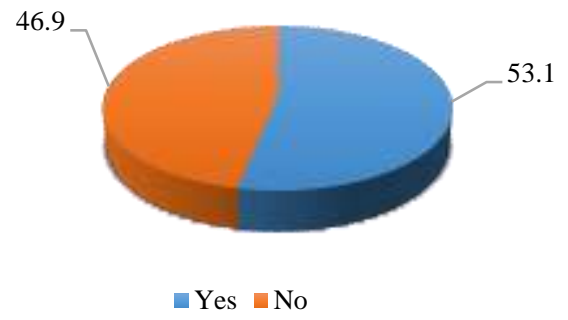

Figure 6. Craftswomen who have their own caves for making hats.

Source: Own Elaboration, 2020

In figure 7 , it is shown that $87 \%$ of the existing caves are in good condition, which means that they are enabled to carry out productive activity.

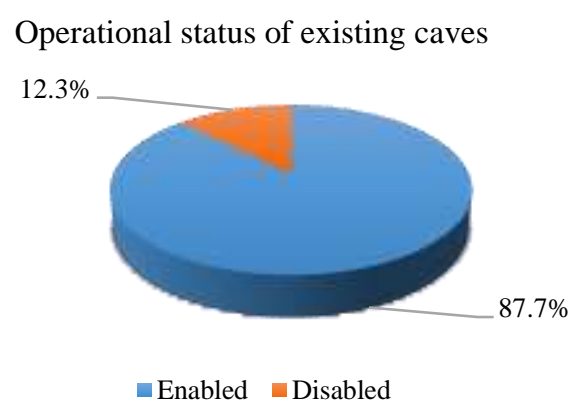

Figure 7 Operational status of existing caves for the elaboration of hats

Source: Own Elaboration, 2020

Only $22.3 \%$ of the craftswomen have received training to improve their production (see figure 8 ).

Training received by the craftswomen

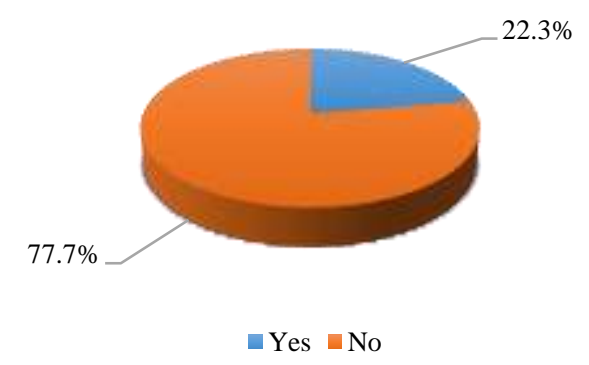

Figure 8 Training received by the craftswomen for the elaboration of the hats.

Source: Own Elaboration, 2020 
Regarding production, it is observed that the hats have different types in terms of their quality, this applies according to the thickness (split) of the palm: since the thicker the fiber with which the fabric is made, the lower quality. For this reason, the thickest fabric is known as a one-batch fabric, while the thickest or finest fabric in its finish is called a four-item fabric.

In table 1 , it is observed that the average time for the elaboration of a hat varies according to the number of games with which it is elaborated, these range from 2.4 to 15 days.

\begin{tabular}{|l|r|r|}
\hline \multicolumn{1}{|c}{ Type of Hat } & \multicolumn{1}{c}{$\begin{array}{c}\text { Average hat- } \\
\text { making time } \\
\text { (in days). }\end{array}$} & $\begin{array}{c}\text { Amount of raw } \\
\text { material (buds) } \\
\text { used per hat. }\end{array}$ \\
\hline a) One split & 2.4 & 6.5 \\
\hline b) Two splits & 6.1 & 11.5 \\
\hline c) Three splits & 12.4 & 17.1 \\
\hline d) Four splits & 15.7 & 18.1 \\
\hline
\end{tabular}

Table 1. Average hat-making time (in days) Source: Own Elaboration, 2020

It is important to mention that the price of the bud varies depending on the place from $\$$ 3.00 to $\$ 20.00$ pesos per unit. This is due to the place of origin of the raw material since what is obtained locally is usually cheaper than if it is brought from other states.

\section{Commercialization}

Regarding marketing, it was observed that $43 \%$ of the surveyed craftswomen made the sale through intermediaries, who, on occasions, buy their hats at very low prices (see figure 9).

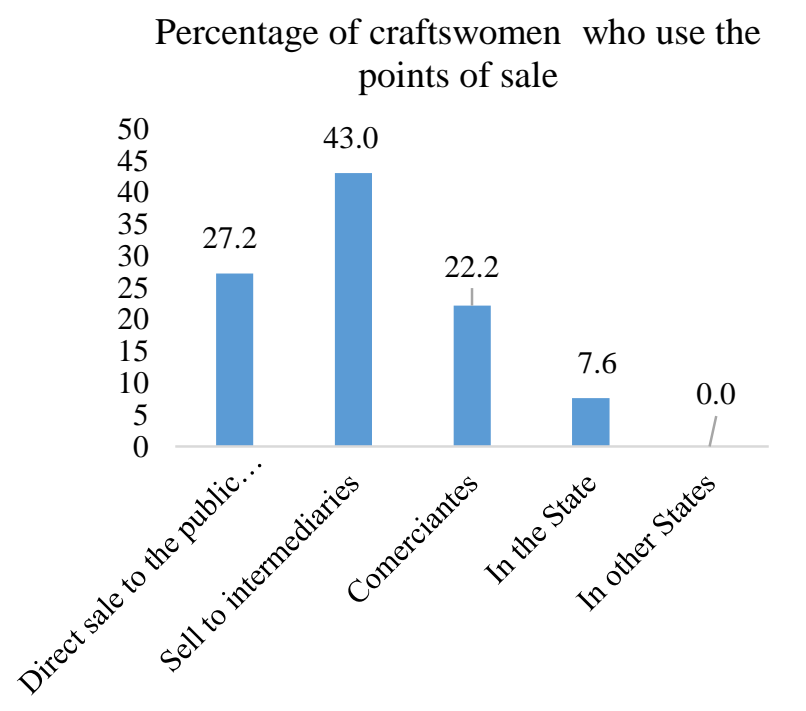

Figure 9. Pattern the hat is marketed.

Source: Own Elaboration, 2020
The prices offered for the hats vary in terms of their fabric and these can cost between $\$ 194.00$ for one item, up to $\$ 1,730.00$ pesos, for four items, according to data shown in table 2 .

\begin{tabular}{|l|r|}
\multicolumn{1}{|c}{ Type of Hat } & $\begin{array}{r}\text { Average price of the finished hat } \\
\text { (in Mexican pesos) }\end{array}$ \\
\hline a) One split & $\$ 194.00$ \\
\hline b) Two splits & $\$ 579.00$ \\
\hline c) Threes splits & $\$ 1,006.00$ \\
\hline d) Four splits & $\$ 1,730.00$ \\
\hline
\end{tabular}

Table 2. Average price of the finished hat (in Mexican pesos).

Source: Own Elaboration, 2020

\section{2) Qualitatives}

The producers of La Palma Jipi-japa sell the raw material directly to the artisans, who in the same way the Ministry of Finance and Public Credit (SHCP) already asks them to invoice the sale of hats and all handcrafted products, making the way difficult to be able to grow in this activity.

The results obtained, it was detected that many of the artisans are only dedicated to the maquila of hats, in a few words they are women who are taken and / or provided with all the raw material for the elaboration of the hat, but they are not the ones that sell to the consumer, this is a worrying situation because they work on a maquila production; which means that the more they make by knitting the hats, the more the profit will be for them, this profit can range from $\$ 194.00$ to $\$ 1,730.00$ per hat.

Next, Table 3 presents the analysis carried out to know the Strengths and Weaknesses related to the Production of the Jipijapa Hat. 


\begin{tabular}{|c|c|}
\hline \multicolumn{2}{|c|}{ Prodution } \\
\hline Strengths & Weaknesses \\
\hline 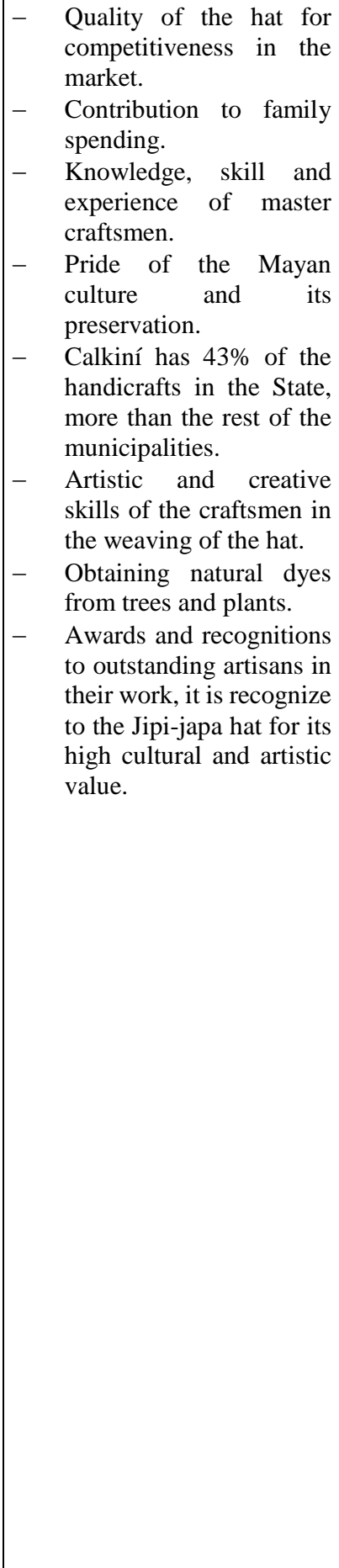 & 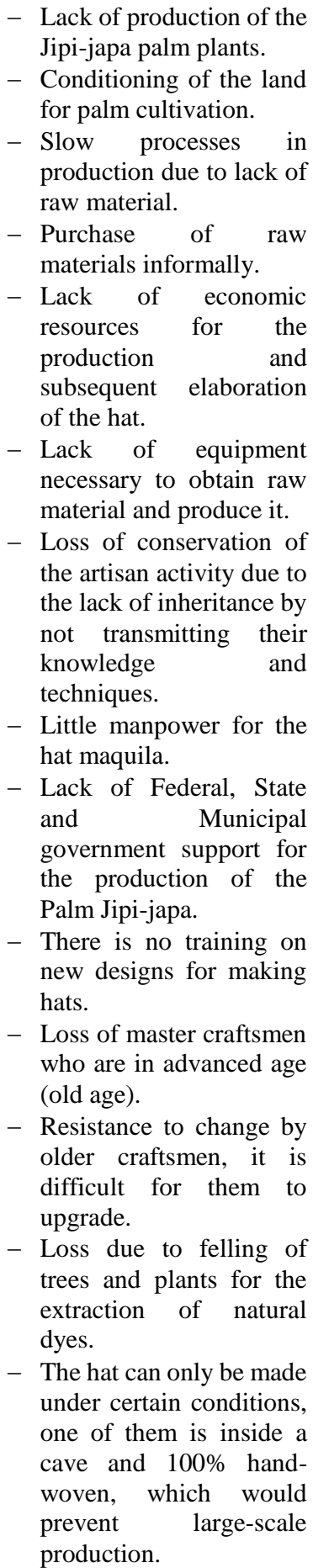 \\
\hline
\end{tabular}

Table 3 Analysis of the Production for the elaboration of the hat

Source: Own Elaboration, 2020

Now with regard to the analysis carried out on the marketing of the Hat (see table 4) and derived from the data described above, the craftswomen fight daily with the so-called intermediaries who buy the hats directly and later sell them two or three times more expensive of its original price.
Which is why many craftswomen have opted for direct sales, having strategies in mutual agreement with some residents of the same Mayan area who attract tourists who come to their population to later take them to the homes of the craftswomen and craftswomen to make direct sales, where the profit logically increases for them and that in the end a percentage of $10 \%$ of these sales is for the intermediary between the tourist and the craftswomen, this comment it is the strategy that has worked for them, but not all the time there are tourists in the place and many times they are in need of having to go with other types of intermediaries that are the formally established companies who buy their products from them at less than $50 \%$ of their value because they have no way of issuing invoices.

\begin{tabular}{|c|c|}
\hline \multicolumn{2}{|c|}{ Commercialization } \\
\hline Strengths & Weaknesses \\
\hline 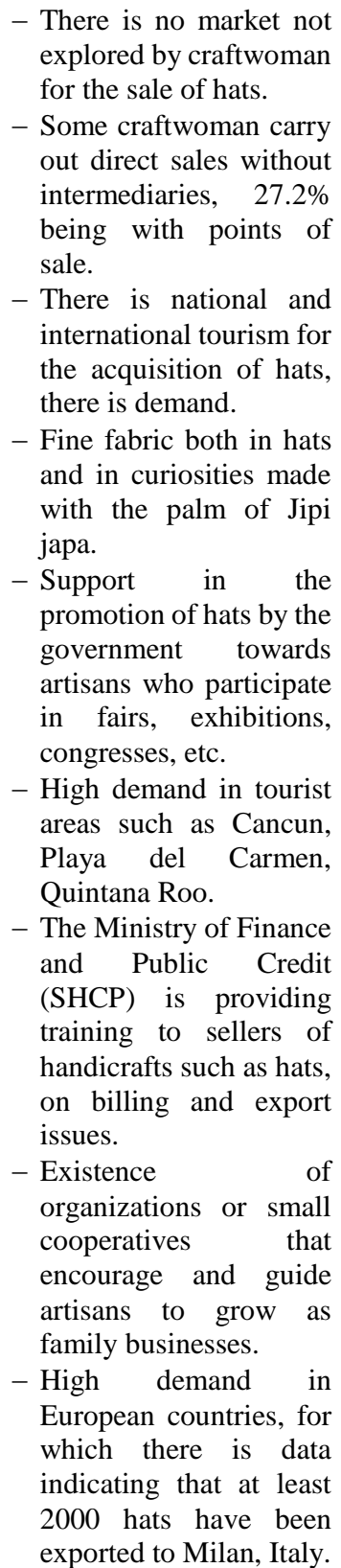 & $\begin{array}{l}\text { - Lack of knowledge in the } \\
\text { management of information } \\
\text { technologies for the sale of } \\
\text { handicrafts. } \\
\text { - The artisans are not } \\
\text { regularized in the SHCP for } \\
\text { the issuance of invoices, they } \\
\text { are unaware of the legal } \\
\text { regulations } \\
\text { - Sales below the real price due } \\
\text { to the lack of issuance of } \\
\text { invoices. } \\
\text { - The abuse of intermediaries } \\
\text { who buy the production of } \\
\text { hats below the real price for } \\
\text { their subsequent sale. } \\
\text { - Existence of people who earn } \\
\text { percentages for taking } \\
\text { tourists to buy the products } \\
\text { (the so-called gringo houses, } \\
\text { as in the case of Villa de } \\
\text { Bécal). } \\
\text { - Lack of channels for } \\
\text { distribution and export due to } \\
\text { ignorance of legal } \\
\text { regulations for } \\
\text { commercialization. } \\
\text { - It depends on the fabric of the } \\
\text { hat and the number of splits } \\
\text { gives the grade of difficulty } \\
\text { of their product. } \\
\text { and time used in its } \\
\text { elaboration. } \\
\text { - There is no cooperative that } \\
\text { includes local handicrafts, } \\
\text { this in order to meet the } \\
\text { demand for orders and } \\
\text { benefit the handicrafts. } \\
\text { Lack of education to the } \\
\text { handicrafts regarding the } \\
\text { ting distribution channels } \\
\text { the }\end{array}$ \\
\hline
\end{tabular}

Table 4. Analysis of the marketing of the hat. Source: Own elaboration, 2020. 


\section{Conclusions}

It is observed in the results that, even though the participation of women in the elaboration of hats has been increasing until reaching $54 \%$ of the total of the producers of the Jipi-japa hat, the new generations are not attracted to this activity, It observes that only $3.8 \%$ of the handicraft are women under 30 years of age.

In production, there is a strong relationship in terms of time and the amount of material used in making the hat, since the higher the quality (greater number of batches), the longer the time and quantity of material.

The price varies according to the quality of the hat, these prices range from $\$ 194.00$ pesos for the hats of a split, to $\$ 1,730.00$ pesos for the hat of four splits. Regarding commercialization, it is observed that the sale to intermediaries is the most used means to commercialize the products, followed by direct sale to the public.

There is a lot of potential in handicraft women, but much support is required from the three levels of government (Municipal, State and Federal) so that traditions and customs are not lost, but above all the importance of women in the preservation of the Jipi-japa hat weaving.

The main risk factors in production are: (1) the increasingly scarce workforce, particularly of the new generations, (2) the lack of raw material that is exacerbated by the immoderate logging of wetlands and the change in land use, (3) the disqualification of caves to carry out this activity and (4) the scarce training of craftswomen. Regarding the commercialization and / or sales, the main risk factors are: (1) the ignorance, of the craftswomen, towards new markets, (2) excessive sale to intermediaries and (3) poor organization in cooperatives or associations by part of the craftswomen.

For this reason, it is necessary to develop strategies that could reverse the current trend because, if this trend continues, there is a risk of disappearing this activity.

\section{Acknowledgments}

To the National Technological Institute of Mexico (TecNM), the Higher Technological Institute of Calkiní in the State of Campeche and the Government of the State of Campeche for supporting the development of the research, the members of the work team and collaborators of the research project with whom I was able to dialogue, to work and build knowledge and of course to the handicrafts and Craftswomen of the Municipality of Calkiní and neighboring Municipalities, who provided important information and experience to build this work.

\section{References}

Álvarez-Gayou J. L. (2003). Cómo hacer investigación cualitativa: Fundamentos y metodología. México: Paidós.

Chuc, C. (1999). El tejido de sombreros de jipi en Bécal Campeche Auge y Decadencia 19301997. Licenciatura en la Universidad Autónoma de Yucatán.

CONEVAL (2014). Indicadores de la pobreza Campeche, 2014 Campeche. Pp. 2-9. Recuperado el 12 de Febrero de 2020 a las 21:00 horas.

https://www.coneval.org.mx/coordinacion/entid ades/Documents/PPT\%20Pobreza14/Campeche $\% 20$ Pobreza\%202014.pdf\#search=pobreza $\% 20$ extrema\%20campeche\%202014

Hernández, R., Fernández, C. y Baptista, P. (2014). Metodología de la investigación. México, D.F. Mc. Graw Hill. Sexta Edición.

Plan Estatal de Desarrollo (2015-2021), Eje 2: Fortaleza Económica. Página 36. Recuperado el 10 de enero de 2020 a las 18:00 horas. de https://www.campeche.gob.mx/ped2015-2021

Plan Estatal de Desarrollo, 2015-2021, Eje 3: Aprovechamiento de la Riqueza. Página 54. Recuperado el 10 de enero de 2020 a las 21 horas. de https://www.campeche.gob.mx/ped2015-2021 
Plan Nacional de Desarrollo (2019-2024), Estrategia II Política Social: Impulsar la reactivación económica, el mercado interno y el empleo. Página 51. Recuperado el 03 de febrero de 2020 a las 13 horas. de https://lopezobrador.org.mx/wpcontent/uploads/2019/05/PLAN-NACIONALDE-DESARROLLO-2019-2024.pdf

Santos, R. y Barroso, F. (2016) Gestión Social. Organizaciones humanas para una sociedad global incluyente. México, Academia de Ciencias Administrativas, A.C.

Sales, F. (2013). Las Artesanías en México: Situación actual y retos. México, D.F. Primera Edición. Centro de Estudios Sociales y de Opinión Pública, Cámara de Diputados/LXII Legislatura. Pág. 20.

UNESCO, (2012). Política de colaboración de la UNESCO con los pueblos indígenas. Recuperado el 8 de Diciembre de 2019 a las 12:00 horas de https://es.unesco.org/indigenouspeoples/policy 